\title{
Zedekiah's fate and the dynastic succession
}

\author{
Pakkala, Juha
}

2006

Pakkala , J 2006 , ' Zedekiah's fate and the dynastic succession ' , Journal of Biblical Literature , vol. 125 , no. 3 , pp. 443-452 . https://doi.org/10.2307/27638374

http://hdl.handle.net/10138/328877

https://doi.org/10.2307/27638374

publishedVersion

Downloaded from Helda, University of Helsinki institutional repository.

This is an electronic reprint of the original article.

This reprint may differ from the original in pagination and typographic detail.

Please cite the original version. 



\title{
Zedekiah's Fate and the Dynastic Succession
}

\author{
JUHA PAKKALA \\ pakkalajuha@yahoo.de \\ University of Helsinki, Helsinki, FIN-00014 Finland
}

Zedekiah's fate has not aroused much scholarly discussion. This is surprising because Zedekiah was Judah's last king and therefore the last reigning heir to David's throne. As a son of Josiah, Zedekiah would represent the Davidic dynastic line. There has been much more attention devoted to the deposed Jehoiachin and his alleged rehabilitation in $2 \mathrm{Kgs} 25: 27-30$, the main question being whether 2 Kgs 25:27-30 presents a positive view about the future of the Davidic dynasty or not (originally von Rad vs. Noth). ${ }^{1}$

Most scholars assume that $2 \mathrm{Kgs} 24: 18-25: 7$ represents a fairly historical rendering of Zedekiah's final days and fate. His sons would have been slain in front of his eyes, and Zedekiah himself would have been blinded and taken in shackles to imprisonment in Babylon. Without much discussion or analysis, the assumption is that there is no reason to doubt the general historicity of this account. $^{2}$

1 Martin Noth, Überlieferungsgeschichtliche Studien: Die sammelnden und bearbeitenden Geschichtswerke im Alten Testament (Halle: Niemeyer, 1943), 12, 108; and Gerhard von Rad, Deuteronomium-Studien (Göttingen: Vandenhoeck \& Ruprecht, 1947), 63-64. This debate has continued; see, e.g., Erìch Zenger, "Die deuteronomistische Interpretation der Rehabilitierung Jojachins," BZ 12 (1968): 16-30, Jon D. Levenson, "The Last Four Verses in Kings," IBL 103 (1984): 353-61; Christopher T. Begg, "The Significance of Jehoiachin's Release: A New Proposal," JSOT 36 (1986): 49-56; and Bob Becking, "Jehojachin's Amnesty, Salvation for Israel? Notes on 2 Kings 25,27-30" in Pentateuchal and Deuteronomistic Studies: Papers Read at the XIIIth IOSOT Congress Leuven 1989 (ed. Chris Brekelmans and Johan Lust; Leuven: Leuven University Press, 1990), 283-93.

22 Kings 24:18-25:7 is viewed as a historical account, for example, by James A. Montgomery, A Critical and Exegetical Commentary on the Book of Kings (ICC; Edinburgh: T\&T Clark, 1951), 560 63; Douglas Rawlinson Jones, Jeremiah (NCB; Grand Rapids: Eerdmans, 1992), 639-44; Georg Hentschel, 2 Könige (NEchtB 11; Würzburg: Echter Verlag, 1985), 124-25; J. Maxwell Miller and John Hayes, A History of Ancient Israel and Judah (London: SCM, 1986), 415; J. Alberto Soggin, 
There are reasons, however, to question whether $2 \mathrm{Kgs} 24: 18-25: 7$ is as unbiased and reliable as usually assumed. First, it is peculiar that the author describes Zedekiah's fate as an eyewitness. The events are presented as if the author of the passage, or the author of the source that was used, had followed the king to the Judean desert and from there to Ribla in Syria. The author claims to have known that Zedekiah personally saw the slaying of his sons (שחטו לעיניו) and was put in shackles. Such details would be expected from an eyewitness. The question is, Who could the eyewitness be? Or, where did the author of $2 \mathrm{Kgs}$ 24:18-25:7 receive such detailed information? It is unlikely that the author himself was the eyewitness, and it is also very doubtful that any Judean was present to witness the events. ${ }^{3}$ He would have to have followed the Babylonian army from the Judean desert, where Zedekiah was captured, to Ribla. He could have been

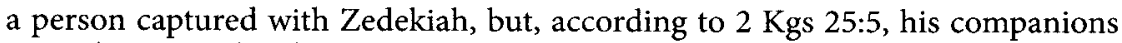
fled (כל־חילו נפצו מעליו). Although it is possible that the king was captured with some of his personal aides and friends, there is no reference to any other person being captured. Moreover, it is doubtful that a co-prisoner, someone who was very close to the king, could have been the source that disclosed embarrassing and humiliating details about the king's fate.

Another possibility is that the account that describes Zedekiah's fate was based on rumors and/or Babylonian propaganda, which were then used by the author of 2 Kgs 24:18-25:7. In principle, it is possible that the Babylonians, for political reasons, would have wanted to spread a report or rumor that Zedekiah's fate was particularly brutal because of his rebellion. This would have functioned as a warning to anyone who planned rebellion. However, since Judah, as a nation, was utterly destroyed, the purpose of such a message in the post-state context is not immediately clear. In any case, even if the Babylonians had circulated such an account, its uncritical acceptance by the author of the DtrH (= Deuteronomistic History) would be of significance. Why would the author of the DtrH accept

A History of Israel: From the Beginnings to the Bar Kochba Revolt AD 135 (2nd ed.; London: SCM, 1993), 264-65; Georg Fohrer, Geschichte Israels (Uni Taschenbücher 708; 6th rev. ed.; Heidelberg/ Wiesbaden: Quelle \& Meyer, 1995), 182-84; and Herbert Donner, Geschichte des Volkes Israel und seiner Nachbarn in Grundzügen 2 (ATD 4/2; Göttingen: Vandenhoeck \& Ruprecht, 1995), 411-12. But note John Applegate, “The Fate of Zedekiah: Redactional Debate in the Book of Jeremiah. Part I," VT 48 (1998): 137.

${ }^{3}$ For example, Walter Dietrich assumes that the author very probably had personal knowledge about Zedekiah's fate (Prophetie und Geschichte: Eine redaktionsgeschichtliche Untersuchung zum deuteronomistischen Geschichtswerk [FRLAN'T 108; Göttingen: Vandenhoeck \& Ruprecht, 1972], 140). According to Ernst Würthwein, the writer of the Deuteronomistic History used a source for the account of Zedekiah (Die Bücher der Könige: 1. Kön 17-2. Kön 25 [ATD 11/2; Göttingen: Vandenhoeck \& Ruprecht, 1984], 475).

${ }^{4}$ Zedekiah had fled with his army to the desert. Although Josephus assumes that Zedekiah also took his wives, children, and friends with him (Ant. 10.8.2 \$\$135-41), 2 Kgs 25:4 refers only to the army, which later abandoned him. 
Babylonian propaganda without question? In other words, it is very unlikely that the author of the DtrH had a reliable source for the events described in 2 Kgs 24:18-25:7. At most, he had a vague rumor or Babylonian propaganda at his disposal, which he could have used as the basis for his account.

Although it is theoretically possible that Zedekiah experienced the fate described in 2 Kgs 24:18-25:7 (but see below), for now our main interest is that the author of the DtrH adopted the account as conclusive and presented it as history, even though he did not have an unproblematic and reliable source for the events. That the author not only described Zedekiah's fate in general terms, as one would expect from an author who does not have a direct source, but also seemed to know curious, even humiliating, details (shackles and Zedekiah seeing the slaughter of his sons), makes the author's approach even more peculiar. There is only one possible conclusion: the author must have had an interest in presenting Zedekiah's fate in such terms. ${ }^{5}$

Furthermore, 2 Kgs 24:18-25:7 is incompatible with some passages in the book of Jeremiah. The characterization of Zedekiah in Jeremiah is confusing, and the picture is ambiguous. There are several passages that, being very probably dependent on 2 Kgs 24:18-25:7, follow the DtrH version of Zedekiah's fate. The king is portrayed in a negative light (e.g., Jer 39:4-7; 52:1-11). In some later additions to Jeremiah, the negative tendency of the DtrH is even amplified, as shown by Hermann-Josef Stipp. ${ }^{6}$ Zedekiah becomes more and more evil. By the end of this development, in the Alexandrian textual tradition of the LXX, Zedekiah is depicted as the source of evil. ${ }^{7}$ It is probable that the negative portrayal of Zedekiah in Jeremiah has its roots in the DtrH.

Our interest lies in the passages of Jeremiah that portray Zedekiah in a more positive light and seem to contradict $2 \mathrm{Kgs} \mathrm{24:18-25:7.} \mathrm{These} \mathrm{passages} \mathrm{were}$ apparently unaffected by the picture of Zedekiah portrayed by the DtrH and must represent a different tradition. It is necessary to examine them more closely.

According to the prophecy in Jer $32: 1-5$ (MT), ${ }^{8}$ Zedekiah will have to face the Babylonian king and be imprisoned, ${ }^{9}$ but there is no reference to the killing of Zedekiah's sons or to his blinding. The lack of reference to blinding is emphasized by the remark that Zedekiah will have to see the king eye to eye (v. 4). This implies that the author of the verse was unaware of or consciously contradicting

${ }^{5}$ The historicity of Zedekiah's fate is further undermined by its similarity to the fate of Jehoahaz, described in $2 \mathrm{Kgs} \mathrm{23:31-35.} \mathrm{Both} \mathrm{were} \mathrm{first} \mathrm{brought} \mathrm{to} \mathrm{Ribla} \mathrm{and} \mathrm{then} \mathrm{imprisoned.}$

${ }^{6}$ Hermann-Josef Stipp, "Zedekiah in the Book of Jeremiah: On the Formation of a Biblical Character," CBQ 58 (1996): 632-38.

${ }^{7}$ Ibid., 638-41. Stipp notes that "the Alexandrian textual tradition was adapted to a stance violently hostile to the last Judean king" (p. 640).

${ }^{8}$ In this article I refer to verses in the MT unless indicated otherwise.

${ }^{9}$ Although vv. $3 b-5$ are presented as a prophecy, it is very likely that the passage was written after the conquest of Jerusalem. 
the tradition that the king was blinded. Most scholars, however, disregard or try

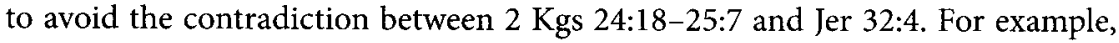
William L. Holladay assumes that the reference to eyes in Jer 32:4, given "the fate that ultimately befell Zedekiah," must be ironic. ${ }^{10}$ This is unlikely, for the context is

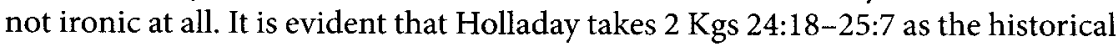
basis and does not question its reliability.

Perhaps the most intriguing detail of this passage is the phrase עד־קדי אתו in v. 5. ${ }^{11}$ The meaning of פקד in this context is not entirely clear. The word could refer to Zedekiah's punishment, "and he will take Zedekiah to Babylon and there he will remain until I punish him," or to the reversal of his fate, "and he will take Zedekiah to Babylon and there he will remain until I attend to him." 12 Although semantically possible, the first alternative is improbable in this context because the loss of kingship and expulsion to Babylon are an extreme punishment already. A reference to an upcoming punishment would make little sense. In fact, is comprehensible only if it refers to the opposite of what has been described in the previous text. The previously described state-misery in the form of imprisonment and shame as described in Jer 32:5a $\alpha$-will continue until Yahweh intervenes. ${ }^{13}$ Therefore, it is probable that the phrase refers to the reversal of Zedekiah's fate. ${ }^{14}$ This is significant in view of 2 Kgs 24:18-25:7, which leaves

${ }^{10}$ William L. Holladay, Jeremiah 2: A Commentary on the Book of the Prophet Jeremiah Chapters 26-52 (Hermeneia; Minneapolis: Fortress, 1989), 213. According to Arnold B. Ehrlich, the text is corrupted and originally contained a negation before the verb: "you will not see the king eye to eye" (Randglossen zur hebräischen Bibel: Textkritisches, Sprachliches und Sachliches, IV Jeremia [Leipzig: Hinrichs, 1912], 324). Such an emendation without any textual support is hazardous, and the evident motive for the emendation is to bring the text into harmony with $2 \mathrm{Kgs}$ 24:18-25:7.

${ }^{11}$ Despite some varying opinions, it is likely that the suffix of את refers to Zedekiah. Wilhelm Rudolph also mentions the possibility that אתו could refer to Nebuchadnezzar (Jeremia [HAT 12; Tübingen: Mohr Siebeck, 1947], 175), but this is unlikely, for the passage deals with Zedekiah's fate, which would then be left open. Moreover, a reference to Nebuchadnezzar's fate would make little sense in this context.

${ }^{12}$ See the different possibilities for interpreting the verb in, e.g., HALAT.

${ }^{13}$ The phrase has been interpreted in many ways. Winfried Thiel assumes that the phrase is a threat to Zedekiah (Die deuteronomistische Redaktion von Jeremia 26-45 [WMANT 52; Neukirchen-Vluyn: Neukirchener Verlag, 1981], 30). According to Rudolph, the phrase may refer to Zedekiah's death (Jeremia, 175), but this would be an exceptional use of the word פקד. Numbers 16:29, to which Rudolph refers in this context, uses the word in connection with death, but there is no reason to assume that פקד means death. It rather refers to visitation or punishment by Yahweh. Rudolph also mentions the possibility that, instead of Zedekiah, Nebuchadnezzar may have been meant (but see $\mathrm{n} .10$ above). Jones suggests that the author may have left the precise meaning open: "until I decide what his future shall be" (Jeremiah, 407-8). Robert P. Carroll notes that in view of other passages in Jeremiah where the word is used $(15: 15 ; 27: 22 ; 29: 10)$, the meaning is probably positive in Jer 32:5 as well, that is, "to visit graciously" (Jeremiah: A Commentary [London: SCM, 1986], 619).

${ }^{14}$ Compare the passage with Jer $27: 22$, where the word פ 2 is similarly used to refer to a reversal of fate, in this case, the fate of the temple vessels. 
practically no space for a reversal of Zedekiah's fate. It would be difficult to reverse the fate of a blinded king whose children had been slain. Therefore, Jer 32:1-5 undermines and contradicts the message of the DtrH concerning Zedekiah. ${ }^{15}$

It is not without interest that the parallel passage in the LXX (39:5) omits the phrase altogether. In the LXX, the verse refers only to Zedekiah's continued imprisonment in Babylon, not to the reversal of his fate. ${ }^{16}$ It is probable that the phrase was later intentionally omitted from the LXX tradition, because its addition would run counter to the general direction of the textual development that gradually made Zedekiah more and more evil. ${ }^{17}$ Moreover, its addition would have been less relevant and more unrealistic in later times when the image portrayed by the DtrH had established itself as the standard. Its omission, on the other hand, would be understandable because it challenged and contradicted 2 Kgs 24:18-25:7. Through its omission, the picture of Zedekiah's fate would have been harmonized. In any case, the phrase עד־פקדי אתו makes less sense if written after the death of Zedekiah, making a late dating unlikely if not impossible. ${ }^{18}$ Consequently, despite the problems caused for conventional views of this king, one cannot avoid the conclusion that the phrase in the MT is original and refers to Zedekiah's rehabilitation and the reversal of his fate.

Like Jer 32:1-5, Jer 34:1-22 seems to contradict 2 Kgs 24:18-25:7. According to Jer 34:5, Zedekiah will die in peace (בשלום תמות) and receive a royal burial as his ancestors did. It is evident that this verse is not compatible with the account in the DtrH. ${ }^{19}$ It would be absurd to characterize the death of a blinded, exiled, and imprisoned man whose sons had been killed before his eyes as peaceful. Against the backdrop of ancient Israelite beliefs, it would be difficult to imagine a more humiliating destiny for a king than the one described in $2 \mathrm{Kgs} \mathrm{25:5-7.} \mathrm{It} \mathrm{is} \mathrm{also}$ significant that Jer 34:5 implies that Zedekiah was a legitimate king who could be likened to his royal fathers (אבותיך המלכים). One cannot avoid the impression that, for the author of this verse, Zedekiah represents the royal line. In comparison, the DtrH ignores what happened to Zedekiah after he was taken to Babylon; there is no word of his death and burial. The silence is intended to imply that Zedekiah

${ }^{15}$ Applegate's suggestion ("Fate of Zedekiah", 155) that the verb is deliberately used in an ambiguous way to refer to both possibilities seems improbable.

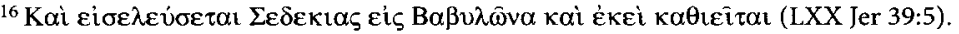

${ }^{17}$ Stipp, "Zedekiah in the Book of Jeremiah," 632-38.

${ }^{18}$ Many scholars assume that the LXX represents the original reading, for example, Holladay, Jeremiah, 203; William McKane, A Critical and Exegetical Commentary on Jeremiah (2 vols.; ICC; Edinburgh/New York: T\&T Clark, 1996), 2:836-37. The LXX is assumed to be secondary by Rudolph, Jeremia, 174-75.

${ }^{19}$ This contradiction has been generally noted in research. For example, Carroll writes: "It is also highly unlikely that such a wretched prisoner should then be accorded the full state funeral honours of a foreign country after his death in prison" (Jeremiah, 642). Carroll continues by trying to show that Jer $34: 5$ is only a conditional statement. Like the consensus, he takes $2 \mathrm{Kgs} 25: 1-7$ as the historical basis and tries to harmonize Jer $34: 5$ with it. 
died shackled and forgotten in prison. The honorable burial of a royal would obviously disturb this picture. In addition, Zedekiah's royal burial would also cause serious problems for the message of $2 \mathrm{Kgs} 25: 27-30$ (see below). ${ }^{20}$

Jeremiah 38 is usually assumed to contain early material that reflects the last days of Judah better than most other texts of the Hebrew Bible. Verses 18 and 23 imply that Zedekiah was taken captive by the Babylonians, but there is no reference to the brutalities mentioned in $2 \mathrm{Kgs} 24: 18-25: 7$. Jeremiah 38 generally implies that Zedekiah was imprisoned in Babylon, but the author does not seem to be aware of any dramatic details that would be worth mentioning.

It is not necessary here to discuss the relative age of these three passages in Jeremiah. Like most of the book, they may have been heavily edited. ${ }^{21}$ It would be very difficult to expose their early cores or to determine their exact editorial development. Nevertheless, it can be established with moderate certainty that they contain material that was unaffected by the view of the DtrH on Zedekiah. Otherwise the existence of elements that conflict with 2 Kgs 24:18-25:7 could not be explained. Moreover, these three passages seem to support one another, providing a generally consistent view of the events related to Zedekiah's fate. They suggest that Zedekiah's imprisonment was a fairly unspectacular event. Before his deportation to Babylon, he would have been taken to see the Babylonian king, but no drama or brutality is connected to the event. This tradition may also have held some hope for the rehabilitation of Zedekiah. The meaning of עד־פקדי אתו in Jer 32:5 is not explicit, but it is probable that the comment was written in a context where Zedekiah lived in exile and imprisonment, when there was still hope that his fate could be reversed. Combined with the idea that honors due to a royal would be given to him at burial (Jer 34:5), it seems that the circles behind this tradition regarded Zedekiah as the legitimate king even after he had been taken to Babylon as prisoner. The historicity of events described in the Hebrew Bible is usually very difficult to determine, but it is clear that if Zedekiah had experienced the fate described in $2 \mathrm{Kgs}$ 24:18-25:7, the alternative tradition reflected in the three passages of Jeremiah would be inconceivable. Consequently, one has to ask what is really going on in $2 \mathrm{Kgs} 24: 18-25: 7$.

We have seen that the author of the DtrH passed on a tradition that he should not have adopted uncritically and, furthermore, provided details that he could not have known. With the challenge posed by the alternative tradition of Jeremiah, the only conclusion to be drawn is that the account in $2 \mathrm{Kgs} 24: 18-25: 7$ serves

${ }^{20}$ For example, puzzled by the contradiction with 2 Kings 25, Rudolph adds בירושלם after in Jer 34:5 (Jeremia, 186). With this addition-but without any textual support-Rudolph reduces the passage to an unfulfilled prophecy. It is evident that 34:2-5 clearly implies that Zedekiah was buried as a king in Babylon. Rudolph's position is an excellent example how a preconception the certainty that $2 \mathrm{Kgs}$ 25:1-7 is reliable history-has influenced an analysis of Jeremiah. Without any textual support, emendations of this kind should be avoided.

${ }^{21}$ See, e.g., Holladay, Jeremiah, 210, 233, 290. 
the author's compositional and other motives more than it provides an unbiased description of historical events. The author wanted to give the impression that Zedekiah's fate was definite and exceptionally humiliating. The king himself was physically ruined and treated as a low criminal. James A. Montgomery has noted also that the blinding may have served to show that Zedekiah's royal potency was destroyed. ${ }^{22}$ Nevertheless, the killing of his sons may be the key to the passage. Zedekiah would not have a successor to the throne and, blinded and imprisoned in Babylon, would not be in a position to beget any further heirs. In other words, the passage makes it clear that Zedekiah's royal line would not continue. ${ }^{23}$

The extinction of Zedekiah's royal line is in accordance with 2 Kgs 25:27-30, which attempts to show that Jehoiachin, representing an alternative royal line,

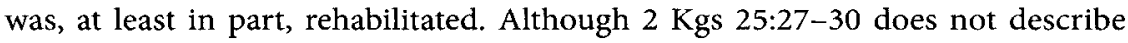
the return of Jehoiachin as a king to Judah, the author implies that he would have been treated like a king by the Babylonians and that there was hope of a complete rehabilitation and a return to Jerusalem to rule as king. When we compare the fates of Jehoiachin and Zedekiah in the $\mathrm{DtrH}$, one cannot avoid the impression that there is a conscious contrast. The main author of $2 \mathrm{Kgs} 24: 18-25: 30^{24}$ implied that Zedekiah's royal line had come to an end, whereas Jehoiachin would represent the future (cf. the contrast between Jer 34:5 and 2 Kgs 25:27-30).

The contrast between these two kings may be seen in some other details as well. For example, it is peculiar that according to 2 Kings Zedekiah's court would have been slain (25:19-21), whereas Jehoiachin's court and family would have been saved (24:12). More than revealing historical circumstances, the author probably wanted to imply that Zedekiah did not have any followers or servants left, whereas Jehoiachin's court was still intact and his family alive. Erich Zenger has further argued that there is a difference in the evaluation of Jehoiachin and Zedekiah. Whereas the deeds of Zedekiah caused Yahweh's anger (2 Kgs 24:20), the evaluation of Jehoiachin lacks this comment. ${ }^{25}$

What is going on in these passages? It is about the dynastic succession. It is

${ }^{22}$ Montgomery, Kings, 562.

${ }^{23}$ One should not exclude the possibility that there is a conscious allusion to the fate of Saul's sons (see 2 Sam 21:4-14), whose killing may also have served the purpose of showing that Saul's dynasty would not continue. This would have removed all doubts about the legitimacy of David's line. Only Mephibosheth, the lame grandson of Saul was saved (2 Sam 21:7). That Mephibosheth was described as lame may have implied that he was not a suitable person to represent a royal line. I warmly thank Dr. Marko Marttila for pointing out that there may be a connection between the fates of Saul's sons and Zedekiah's sons.

${ }^{24}$ The passage was certainly edited, but in relation to Zedekiah and Jehoiachin there does not seem to be any change in attitude or perspective.

${ }^{25}$ Zenger, "Die deuteronomistische Interpretation," 29. He has further noted that Zedekiah is reported to have acted not like Jehoiachin but like Jehoiachim, Jehoiachin's father. According to Zenger, this was done consciously so as to put Jehoiachin and Zedekiah on the same level. 
about which royal line is legitimate. By deposing Jehoiachin and replacing him with Zedekiah, Nebuchadnezzar had created two branches of the royal line (2 Kgs $24: 8-17) .^{26}$

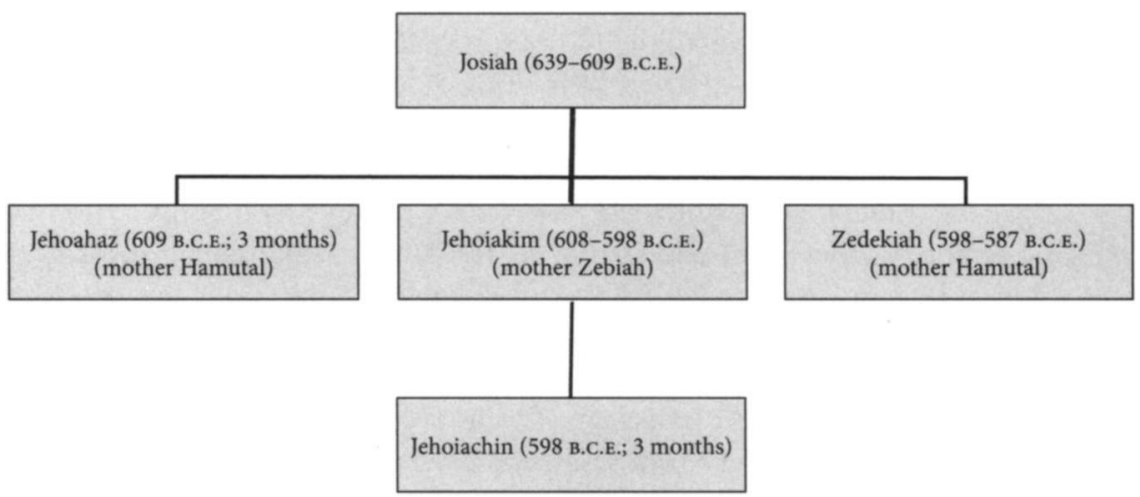

When examined in the context of the events, the legitimacy of both lines could be justified. Both Zedekiah and Jehoiachin served as kings and could therefore have a claim to the throne. Zedekiah was Josiah's son, whereas Jehoiachin was Josiah's grandson. Both were thus direct descendants of the royal line. In addition, Zedekiah had the advantage of having been the last king. Moreover, his reign was much longer than that of Jehoiachin: eleven years versus three months. Jehoiachin did not have any time to establish his kingship. In other words, it would not have been easy to reject the legitimacy of Zedekiah's line in favor of Jehoiachin. The only way to undermine Zedekiah's line would have been to show that it had ended and could never provide an heir to the throne, and $2 \mathrm{Kgs}$ 24:18-25:7 serves this purpose. The emphasis of the DtrH on this issue is incomprehensible if the dynastic succession was clear and undisputed. The dynastic succession seems to have been a relevant and acute issue during the time $2 \mathrm{Kgs}$ 24:18-25:30 was written. ${ }^{27}$ The question is all the more important once we have established that there was a competing tradition. This indicates that there must have been an early exilic dispute about the dynastic line. In the first years after the destruction of Jerusalem there was still hope that the Davidic dynasty would rise to the throne,

${ }^{26}$ In fact, there were three potential royal lines, since Jehoahaz, a son of Josiah, had also been deposed ( $2 \mathrm{Kgs}$ 23:33-34). His whereabouts and fate are unknown after he was captured and brought to Ribla (v. 33). According to Jer 22:10-12, he died in prison.

${ }^{27}$ In comparison, in 2 Chronicles 36 the fates of both kings are disregarded, evidently because the issue had become irrelevant. Hope for the reestablishment of the dynasty had faded by the time of the Chronicler(s)'s activity. For him (them), the future of Israel as a nation (e.g., its identity and existence) was a much more relevant issue. 
but, with two existing lines, there emerged a disagreement over which one would represent the dynasty.

In addition to the passages already mentioned, Jer 22:24-30 could also be a vestige of this conflict. According to this passage, Jehoiachin would not have a follower to the throne (v. 30). Instead, he would be thrown out like a broken and

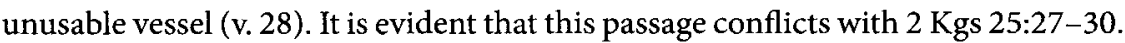
It seems to reject Jehoiachin's dynastic line. Although Zedekiah is not mentioned, the passage is well in line with those passages in Jeremiah that are more positive to the legitimacy of Zedekiah.

The tradition that Zedekiah represents the legitimate king must derive from a period when Zedekiah or at least his descendants were still alive and had realistic claims to the throne. The critical attitude of $2 \mathrm{Kgs} 24: 18-25: 7$ to Zedekiah seems to confirm the existence of such claims. The author of this passage wanted to reject those claims by asserting that Zedekiah's sons had been killed. He would have implied that all who claim to be of the line of Zedekiah were usurpers and liars. Such a critical attitude and the extent of the attempt to humiliate Zedekiah are comprehensible only if the author felt that Jehoiachin's line was threatened by Zedekiah or his line. One does not attack something that does not pose a threat.

Unfortunately, we do not have any information about Zedekiah's children

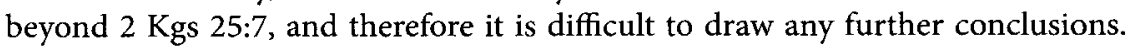
The most probable context for the dispute is a situation in which both Zedekiah and Jehoiachin were still alive and were still potentially eligible for the throne. It is significant that the death of neither king is described in 2 Kings. In comparison, the deaths of all other Judean kings are described in the books of Kings. By describing Zedekiah's death, the author of 2 Kgs 24:18-25:30 certainly served the purpose of showing that Zedekiah's line was not going to continue.

Considering the potentially biased nature of $2 \mathrm{Kgs} 24: 18-25: 7$, one may also cast some doubt on the historicity of Zedekiah's escape from the besieged Jerusalem (25:4). It is improbable that the Babylonians would make such a mistake in their military strategy that the entire Judean army (כל־אנשי המלחמה) could have escaped from the besieged city. The Babylonian army was a professional military machine experienced with sieges and would certainly have been aware that the king and the elite would try to escape when the city was about to fall.

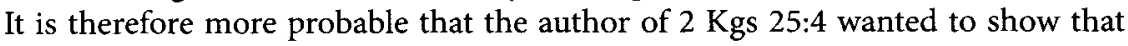
Zedekiah was a coward who only wanted to save his own neck and left the people to suffer the consequences of his unwise politics. This would be well in accordance with the author's interest in showing that Zedekiah was a failure as a ruler.

One should also be skeptical about the historicity of Jehoiachin's rehabilitation as described in $2 \mathrm{Kgs} 25: 27-30$. Although some change in attitude toward imprisoned kings may have occurred in 562/561 B.C.E., ${ }^{28}$ it is difficult to see

${ }^{28}$ See, e.g., Becking, "Jehojachin's Amnesty," 283-90. 
what would have been the motive of the new Babylonian king, Evil-Merodach (Amel-Marduk), in raising Jehoiachin, an ex-king of an insignificant state destroyed almost three decades earlier, above all other imprisoned kings. The idea that Jehoiachin received special treatment is certainly exaggerated. More than revealing a historical reality, the passage serves the purpose of showing that the royal line represented by Jehoiachin was recognized even by the Babylonians, whereas Zedekiah's line was forgotten. The message may be that the supporters of Zedekiah's line would have to challenge even the Babylonians, who stood behind Jehoiachin.

Although without additional information, it may not be possible to say more about the historical circumstances concerning Zedekiah and Jehoiachin, some issues in the composition of the DtrH are illuminated. The author's interest in the kingship and dynasty is not only about the continuity of the dynasty, ${ }^{29}$ but also about the continuity of a certain dynastic line that he favored. Moreover, if we accept that the dynastic conflict was an important theme of the history writer, it confirms that $2 \mathrm{Kgs} 25: 27-30$ is an inherent part of the composition. Several scholars assume that these verses are a later addition, ${ }^{30}$ but without $2 \mathrm{Kgs}$ 25:27-30, the emphasis on Zedekiah's negative fate would not be comprehensible. If we accept that Zedekiah was still alive during the time of writing, it is probable that the author wrote in the time shortly after 562 B.C.E. ${ }^{31}$ Since Zedekiah was approximately fifty-seven years old in 562 B.C.E., he would have ceased to pose a serious challenge to Jehoiachin not long after that date.

It now seems evident that the history writer was preoccupied with the kingship not only in terms of its history and the continuity of the Davidic dynasty. He wrote in a context where two dynastic lines could justify their legitimacy. The history writer was a firm supporter of one line. He rejected Zedekiah's line as a dead end in favor of Jehoiachin. Perhaps the conflict over which was the legitimate line played a larger role in the whole composition of the $\mathrm{DtrH}$, but this lies beyond the scope of this article. In any case, it is significant that, despite massive editing by redactors influenced by the $\mathrm{DtrH}$, the book of Jeremiah preserves some vestiges of an alternative tradition that treats Zedekiah as the legitimate king whose line could provide heirs to David's throne.

${ }^{29}$ See Timo Veijola, Das Königtum in der Beurteilung der deuteronomistischen Historiographie: Eine redaktionsgeschichtliche Untersuchung (AASF B 198; Helsinki: Suomalainen Tiedeakatemia, 1977), 115-19.

${ }^{30}$ E.g., Dietrich has argued that 2 Kgs 25:27-30 was later added by DtrN (Prophetie und Geschichte, 140-43); similarly, Hentschel, 2 Könige, 124-25; and Jones, Jeremiah, 648. According to Würthwein, 2 Kgs 25:22-30 was added by a post-Dtr editor (Die Bücher der Könige, 481-84).

31 The last events described in 2 Kings can be dated to 562 B.C.E., for 2 Kgs 25:27 refers to the thirty-seventh year after the beginning of the exile. 